\title{
Modulatory effect of Calendula officinalis on altered antioxidant status and renal parameters in diabetic rats
}

\author{
Pawan K Verma ${ }^{1 *}$, Rajinder Raina ${ }^{1}$, Mudasir Sultana ${ }^{1}$, Maninder Singh ${ }^{2}$ \\ ${ }^{1}$ Division of Veterinary Pharmacology and Toxicology, Faculty of Veterinary Sciences and Animal Husbandry, SKUAST-J, R S Pura, Jammu, \\ 181102, Jammu \& Kashmir, India \\ ${ }^{2}$ Division of Veterinary Public Health and Epidemiology, Faculty of Veterinary Sciences and Animal Husbandry, SKUAST-J, R S Pura, Jammu, \\ 181102, Jammu \& Kashmir, India
}

Received: Jan 5, 2017, Revised: Jan 30, 2016, Accepted: Feb 2, 2017

\begin{abstract}
Calendula officinalis (Family Compositae) flowers are recognized as safe substance for food use by Food and Drug Administration. Present study was aimed to determine the modulatory effect of floral extracts of $C$. officinalis administrations on mean blood glucose (MBG), per cent glycosylated hemoglobin (HbAlc), lipid profile [(total cholesterol (TC), triglycerides (TG), low and high density lipoproteins (LDL, HDL)], antioxidant and renal parameters in streptozotocin (STZ) induced diabetic rats. Increased ( $\mathrm{P}<0.05)$ levels of MBG and $\mathrm{HbA1c}$ fraction indicate the induction of diabetes in rats. Enhanced ( $\mathrm{P}<0.05) \mathrm{TC}, \mathrm{TG}, \mathrm{LDL}$, total oxidant status (TOS), oxidative stress index (OSI), malondialdehyde (MDA) levels, and renal indices were observed in blood of diabetic rats. However, levels of HDL, protein profile, total antioxidant status (TAS), glutathione (GSH), total thiols (TTH) and activities of catalase (CAT), superoxide dismutase (SOD), glutathione peroxidase (GPx), glutathione-s-transferase (GST) and glucose-6-phosphate dehydrogenase (G6PDH) were significantly reduced in diabetic rats. Repeated administrations of ethanolic floral extract of $C$. officinalis reduced the enhanced levels of MBG, HbA1c and TC while restored OSI, TTH, GSH, CAT, SOD, GST and MDA levels; it also increased activities of G6PDH and GPx in diabetic rats compared to untreated diabetic rats. Hypoglycemic, hypolipidemic, restored antioxidant level, and reduced altered renal functions by the floral extract of $C$. officinalis in diabetic rats. Further, the modulatory effect was better in aqueous as compared to ethanolic floral extract of $C$. officinalis.
\end{abstract}

Keywords: Calendula officinalis, malondialdehyde, hypoglycemic, antioxidant, diabetes

Pharm Biomed Res 2016; 2(4): 52-64

\section{Introduction}

Diabetes mellitus, a most common endocrine disorder is the major cause of ill health worldwide (1). The disorder will continue to grow globally due to an aging population, growth of population size, urbanization, high prevalence of obesity and sedentary life style (2). Defect in insulin secretion from $\beta$-cells of pancreas and/or insulin action on the central and peripheral organs are often primary causes of manifestation of disease (3). Experimental diabetes in animals provides considerable insight into the physiological and biochemical derangement in important vital organs of the body particularly in renal diseases. Studies showed diabetic complications are primarily due to increased non-enzymatic and progressive glycation of proteins with consequently increased formation and accumulation of glucose derived advanced glycation end products (AGEs) $(4,5)$ in tissue leading to oxidative damage. Further persistent decrement in the level of insulin adversely deranges the carbohydrate and lipid metabolism in mammalian tissues leading to secondary complications.

Application of phytochemicals for the treatment of various ailments has been used since dawn of civilization. Herbal drugs are undoubtedly attractive and reliable alternative for management of diseases due to their easy accessibility, efficacy and importantly being natural herbs are considered to be safe (6). Ethnobotanical reports suggest that more than 800 plants to 
possess antidiabetic potential (7). Many traditional plant formulations are being used and claiming to be effective for the management of diabetes throughout world. Botanicals are being rich in natural antioxidants (flavonoids, carotenes, terpenoids etc) not only improve insulin secretion from $\beta$-cells of pancreas but also neutralizes excessive generated free radicals due to deranged cellular metabolism thereby reducing the diabetic complications (8).

Calendula officinalis (Family Compositae) is being used in folklore system of medicine due to its high medicinal potential. Dried flower is used as a spice and falls under generally recognized as safe (GRAS) category by the USFDA. Various calendula preparations are approved for their use in traditional medicine by the European Medicines Agency (9). Calendula extract contains a number of phytoconstituents and its chemical composition depends on the extraction method and/or part of plant used for the extraction. Floral extract of $C$. officinalis have high concentration of terpenoids and flavonoids compounds compared to other parts of the plant $(10,11)$. Additionally, floral extract of the plant are rich source of polyunsaturated fatty acids (12), mineral substances (13) and vitamin C (14) which adds to its ethanomedicinal potential. Calendula flower is often used in skin care products; it assists the cell rejuvenation and wound healing (15). Studies have reported that plant also posses hepatoprotective $(16,17)$, nephroprotective $(17,18)$ anti-inflammatory (19) potential of the plant extracts. Therefore, present study was aimed to determine the modulatory effect of $C$. officinalis administrations on glycemic index, antioxidant and renal parameters in streptozotocin (STZ) induced diabetic rats.

\section{Materials and method}

Collection and preparation of extracts

The flowers of $C$. officinalis were collected from different parts of Jammu (India). Plant sample was taxonomic identified by Taxonomist, Department of Botany, University of Jammu (AU-2875). Sufficient fresh flowers were collected and air-dried in shade (temperature not exceeding $40{ }^{\circ} \mathrm{C}$ ) for 3-4 weeks. Air dried flowers were pre-crushed and later pulverized into fine powder using electric blender. The aqueous extract was prepared by soaking dry powder in 1:10 ratio in distilled water for $72 \mathrm{~h}$ with intermittent shaking. After $72 \mathrm{~h}$ of soaking, the contents were filtered through filter paper $(0.45 \mu \mathrm{m})$ and filtrate was concentrated under reduced pressure using rotatory evaporator (temp 50-55 $\left.{ }^{\circ} \mathrm{C}, 10-15 \mathrm{rpm}\right)$. The ethanolic extract was prepared by using ethyl alcohol in extract container of soxhlet apparatus according to standard method. The dried aqueous and ethanolic floral extracts of $C$. officinalis were stored at $4{ }^{\circ} \mathrm{C}$ in air tight containers. Per cent extractability of aqueous and ethanolic floral extracts of C. officinalis was 23.62 and $17.61 \%$ respectively (11). The extracts were reconstituted in $0.1 \%$ carboxy methyl cellulose (CMC) for oral gavage in wistar rats.

\section{Chemicals and experimental animals}

Streptozotocin (2-deoxy-2-(\{[methyl (nitroso) amino] carbonyl $\}$ amino)- $\beta$-D-glucopyranose); ABTS (2,2'azinobis (3-ethylbenzothiazoline 6-sulphonate) were procured from the Sigma-Aldrich, USA and other chemicals used in the study were analytical grade. Adult wistar rats of either sex weighing 180-200gm were procured form Indian Institute of Integrative Medicine, Jammu, INDIA used for the experimental study. Procured rats were acclimatized in the laboratory conditions for a period of more than 2 weeks prior to start of experiment. Animals were provided standard pelleted ration and ad libitum drinking water under standard managemental conditions $\left(22 \pm 3{ }^{\circ} \mathrm{C} 50-60 \%\right.$ relative humidity and $12 \mathrm{~h}$ light-dark cycles). The experimental protocol was approved and monitored by Institutional Animal Ethics Committee (IAEC) and all the experimental animals were kept under constant observation during entire period of study (FVSc/C11/2456-68).

\section{Experimental design}

Diabetes was induced by single intra-peritoneal injection $(55 \mathrm{mg} / \mathrm{kg}$ ) of STZ, freshly dissolved in $0.1 \mathrm{M}$ cold citrate buffer (pH 4.5) (20). Five days after STZ injection, fasting blood glucose of the rats was estimated and the rats having blood glucose above 225 $\mathrm{mg} / \mathrm{dl}$ were considered as diabetic and included in the experimental trial. Eighteen normal rats divided in Group I, II and III, received $1 \mathrm{ml} /$ day CMC, aqueous and ethanolic floral extracts of $C$. officinalis, respectively. Whereas 24 diabetic rats were divided into four groups viz. IV rats were diabetic and receiving no 
treatment and served as diabetic control and Group V received glibenclamide $(10 \mathrm{mg} / \mathrm{kg}$ orally) as a standard antidiabetic drug. Group VI and VII diabetic rats received $300 \mathrm{mg} / \mathrm{kg}$ BW aqueous and ethanolic floral extract of $C$. officinalis, respectively. All treatments were administered daily for 21 days in between 10.00-11.00 AM. Dose of the plant extract was calculated on the basis of lethal dose and other pharmacological potential $(9,15,18)$.

\section{Collection and processing of samples}

3-4 mLblood sample from each rat was collected directly from cardiac puncture in sterilized tube containing heparin after 21 days of repeated administrations. Blood glucose level was determined immediately using glucometer (Contour ${ }^{\circledR}$ TS, Bayer Pharmaceuticals Pvt. Ltd. India). Part of blood sample was used for the determination of reduced glutathione (GSH), hemoglobin $(\mathrm{Hb})$ and glycosylated fraction of hemoglobin $(\mathrm{HbA} 1 \mathrm{c})$. The remaining part of blood samples was centrifuged at $4000 \mathrm{rpm}$ for $10 \mathrm{~min}$; plasma was collected in glass vials for the estimation of plasma proteins, lipid, muscular and renal parameters. Glycosylated hemoglobin (HbAlc) fraction was determined based on ion exchange method (21) based kit (Transasia Bio-Medicals Ltd, India) using UV-visible spectrophotometer (UV-1601, Shimadzu).

\section{Assaying of antioxidant and renal parameters}

Total antioxidant status (TAS) was determined spectrophotometrically by using 2,2'-azinobis (3ethylbenzothiazoline 6-sulphonate) (ABTS) according to the standard method (22); final TAS values were expressed as $\mathrm{mM}$ of ascorbic acid equivalents in the plasma. Similarly, TOS level was measured using a novel automated method developed by Erel (23) and results expressed in terms of $\mu \mathrm{mol} \mathrm{H}_{2} \mathrm{O}_{2}$ Equiv./L. The percent ratio of TOS to TAS level was used for determination of oxidative stress index (OSI) (24). The activity of G6PDH was assessed based upon the ability of enzyme to catalyze the conversion of Glucose-6phosphate and $\mathrm{NADP}^{+}$to 6-phosphogluconolactone and NADPH (reduced nicotinamide adenine dineucleotide phosphate) as per the method described by Deutsch (25). The enzymatic parameters viz. catalase (CAT), glutathione peroxidase (GPx), superoxide dismutase (SOD) and glutathione-S-transferase (GST) were determined as using standard methods $(26,27,28,29)$. Total thiols (TTH) level was determined in plasma as per the standard protocol and the concentration of total thiols $(\mathrm{mM})$ was expressed using reduced glutathione as a standard (30). Similarly, malondialdehyde (MDA) level in plasma (nmole of MDA formed $/ \mathrm{mg}$ of $\mathrm{Hb} / \mathrm{h}$ ) was determined to estimate the membrane lipid peroxidation (31). The level of reduced blood glutathione (GSH) was determined as per the standard method (32). Activities of aspartate and alanine aminotransferase (AST, ALT), alkaline phosphatase (ALP), lactate dehydrogenase (LDH), gamma glutamyl transferase (GGT), levels of plasma proteins, albumin, creatinine (CR), blood urea nitrogen (BUN), lipid profile viz. total cholesterol (TC), triglycerides (TG), high density lipoproteins (HDL) and low density lipoproteins (LDL) were determined by standard kits (Transasia Bio-Medicals Ltd, India) using Chemistry Analyzer (CHEM-7, ERBA, Mannheim).

\section{Statistical analysis}

The values are presented in mean \pm standard error. Biochemical and antioxidant parameters were analyzed for analysis by analysis of variance in completely randomized design using the Duncan Multiple Range Test at $5 \%$ level of significance (SPSS 16.0, IBM, USA).

\section{Results}

Alterations in MBG, $\mathrm{HbAlc}$, plasma proteins, lipids, antioxidant and renal parameters of blood were assessed in diabetic rats and modulatory effect following repeated administrations of aqueous and ethanolic floral extracts of C. officinalis.

Effects on mean blood glucose and glycosylated $\mathrm{Hb}$ ( $H b A l c)$

Single oral dose administration of STZ significantly $(\mathrm{P}<$ 0.05 ) increased the MBG level as compared to normal rats. Glibenclamide treatment in diabetic rats significantly $(\mathrm{P}<0.05)$ reduced the MBG level and these values are significantly $(\mathrm{P}<0.05)$ higher from the control group (Table 1). Repeated administrations with either aqueous or ethanolic floral extract to diabetic rats significantly $(\mathrm{P}$ $<0.05$ ) reduced MBG as compared to diabetic rats but levels were still significantly $(\mathrm{P}<0.05)$ higher than the normal control. Further aqueous extract treated group exhibited significantly $(\mathrm{P}<0.05)$ lower 
Table 1: Effect of aqueous and ethanolic floral extracts of $C$. officinalis administrations on mean blood glucose (MBG) hemoglobin $(\mathrm{Hb})$ and glycosylated $\mathrm{Hb}(\mathrm{HbA} 1 \mathrm{c})$ in plasma of diabetic rats

\begin{tabular}{lccc}
\hline \multicolumn{1}{c}{ Groups } & MBG & Hb & HbA1c \\
\hline Normal control & $86.83^{\mathrm{a}} \pm 5.18$ & $12.89^{\mathrm{bc}} \pm 0.29$ & $5.19^{\mathrm{a}} \pm 0.16$ \\
\hline Aqueous extract & $99.67^{\mathrm{a}} \pm 7.12$ & $11.37^{\mathrm{bc}} \pm 0.31$ & $5.58^{\mathrm{a}} \pm 0.21$ \\
\hline Ethanolic extract & $90.50^{\mathrm{a}} \pm 5.02$ & $11.48^{\mathrm{bc}} \pm 0.38$ & $5.30^{\mathrm{a}} \pm 0.15$ \\
\hline Diabetic control & $205.33^{\mathrm{d}} \pm 7.15$ & $8.45^{\mathrm{a}} \pm 0.45$ & $8.75^{\mathrm{d}} \pm 0.21$ \\
\hline Diabetic + Glibenclamide & $124.67^{\mathrm{b}} \pm 5.08$ & $11.63^{\mathrm{c}} \pm 0.48$ & $6.33^{\mathrm{b}} \pm 0.15$ \\
\hline Diabetic + Aqueous extract & $126.00^{\mathrm{b}} \pm 11.75$ & $11.66^{\mathrm{b}} \pm 0.27$ & $6.17^{\mathrm{b}} \pm 0.36$ \\
\hline Diabetic + Ethanolic extract & $177.50^{\mathrm{c}} \pm 7.70$ & $9.95^{\mathrm{b}} \pm 0.28$ & $7.91^{\mathrm{c}} \pm 0.23$ \\
\hline $\begin{array}{l}\text { Values are given as mean } \pm \text { SE of } 6 \text { animals unless otherwise stated } \\
\text { Values having different superscripts (a, b, c \& d) in a column are statistically different from one another at } 5 \% \\
\text { level of significance }\end{array}$ \\
$\begin{array}{l}\text { Values of Hb (hemoglobin) are expressed in gm/dl } \\
\text { Values of HbA1c and MBG (mean blood glucose) are expressed in Per cent glycosylated Hb and mg/dl } \\
\text { respectively }\end{array}$
\end{tabular}

MBG as compared to ethanolic floral extract of $C$. officinalis administrations. In diabetic rats significant $(\mathrm{P}<0.05)$ reduction in the $\mathrm{Hb}$ and significant increased $(\mathrm{P}<0.05)$ level of HbA1c were observed as compared to normal control. Treatment with glibenclamide in diabetic rats significantly $(\mathrm{P}<0.05)$ lower the level of $\mathrm{HbAlc}$ than the diabetic rats. Similarly treatment with aqueous floral extract in diabetic rats significantly $(\mathrm{P}<0.05)$ lowered the per cent HbA1c level as compared to diabetic rats, but these values were still significantly $(\mathrm{P}<0.05)$ higher than the control animals. Aqueous floral extract was found to be more potent in restoring the concentration of $\mathrm{HbAlc}$ than the ethanolic floral extract of $C$. officinalis.

\section{Effect on plasma lipids and proteins profile}

Levels of TC, TG and LDL were significantly $(P<0.05)$ increased and reduction $(P<0.05)$ in level of HDL were seen as compared to control values. Treatment with glibenclamide significantly $(\mathrm{P}<0.05)$ reduced the levels of TC, TG and LDL as compared to diabetic rats, but these values were significantly $(\mathrm{P}<0.05)$ higher than the control group. Similarly repeated administration of either aqueous or ethanolic extract in diabetic rats significantly $(\mathrm{P}<0.05)$ reduced the levels of TC, TG, LDL and significantly $(\mathrm{P}<0.05)$ increased HDL. Aqueous extract of $C$. officinalis was more effective than ethanolic extract in lowering triglycerides, LDL and increasing HDL and these values were not statistically different from the normal control (Table 2). In diabetic rats concentrations of total plasma proteins, albumin and globulin were significantly $(P<0.05)$ reduced than their respective normal control. Administration of glibenclamide significantly $(\mathrm{P}<0.05)$ increased level of total plasma proteins but the values were significantly $(\mathrm{P}<0.05)$ lower from the control group whereas level of albumin was not differ significantly. Repeated administration of either aqueous or ethanolic floral extract of $C$. officinalis in diabetic rats didn't restore the values of total plasma proteins and albumin in diabetic rats (Table 3).

\section{Effect on biochemical parameters}

Activities of ALP, LDH, AST and ALT were significantly $(\mathrm{P}<0.05)$ higher in diabetic rats as compared to their respective activities in normal control. Treatment with glibenclamide significantly $(\mathrm{P}$ $<0.05$ ) reduced the AST, ALT, ALP and LDH activities as compared to diabetic control but values were significantly $(\mathrm{P}<0.05)$ higher from the normal control with the exception of ALP and ALT nonsignificantly different from normal control. Treatment with either aqueous or ethanolic floral extract of $C$. officinalis significantly $(\mathrm{P}<0.05)$ reduced the activities of AST, ALT, ALP and LDH as compared to diabetic rats but these activities excepting ALT were still significantly $(\mathrm{P}<0.05)$ higher than the normal control in rats administered ethanolic extract of $C$. officinalis. 
Table 2: Effect of aqueous and ethanolic floral extracts of $C$. officinalis administrations on plasma lipid profile i.e. total cholesterol (TC), triglycerides (TG), High and low density lipoproteins (LDL and HDL) of diabetic rats

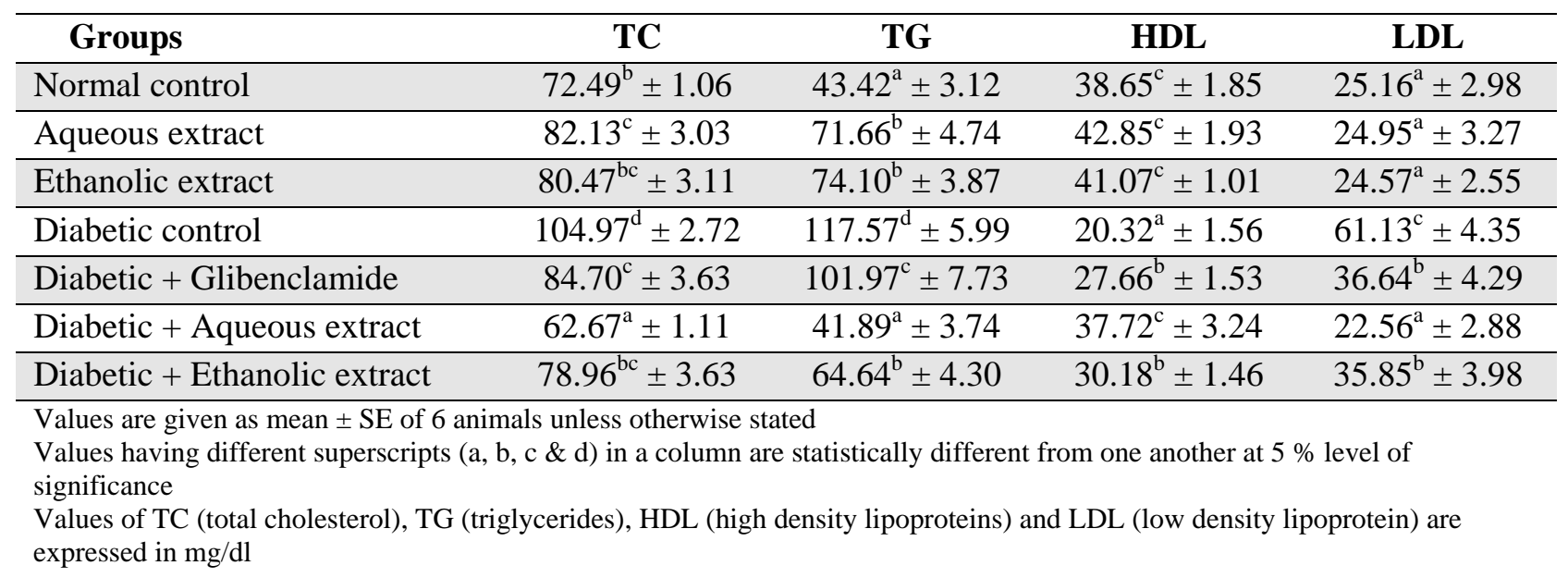

Significant $(\mathrm{P}<0.05)$ increased levels of BUN and CR were observed in diabetic rats as compared to normal rats. Daily treatment with glibenclamide significantly $(\mathrm{P}$ $<0.05)$ reduced BUN and CR levels as compared to diabetic rats whereas value of BUN was still significantly higher than normal control. Either of the floral extract of $C$. officinalis used for daily treatment failed to reduce the levels of BUN, CR in any significant manner from their counterpart in the diabetic group (Tables 3 and 4).

\section{Antioxidant parameters in blood}

Increased $(\mathrm{P}<0.05)$ levels of TOS, OSI and significant $(\mathrm{P}<0.05)$ reduction in TAS were observed in diabetic rats as compared to normal rats. Repeated treatments with glibenclamide normalize the levels of TAS, TOS and OSI in diabetic rats. Treatment with aqueous floral extract of C. officinalis in diabetic rats significantly ( $\mathrm{P}<$ $0.05)$ increased the TAS level but this level was still significantly $(\mathrm{P}<0.05)$ lower than the normal rats. However, treatment didn't lower the increased levels of TOS and OSI as compared to normal rats although the levels were significantly $(\mathrm{P}<0.05)$ reduced than the levels of diabetic group. Treatment with ethanolic floral extract of $C$. officinalis in diabetic rats restored the TOS and OSI levels and significantly $(\mathrm{P}<0.05)$ improved the level of TAS as compared to control group. GSH and TTH were significantly $(\mathrm{P}<0.05)$ reduced in diabetic rats but treatment with glibenclamide for 21 days these were significantly $(\mathrm{P}<0.05)$ increased bringing TTH levels similar to control group. Treatment with aqueous floral extract of $C$. officinalis non-significantly increased GSH and TTH as compared to diabetic rats but daily administration of ethanolic floral extract of $C$. officinalis in diabetic rats restored GSH and TTH levels were similar to the normal control (Figure 1).

Activities of antioxidant enzymes like CAT, SOD, GPx, GST and G6PDH were significantly $(\mathrm{P}<0.05)$ reduced in untreated diabetic rats as compared to normal rats. Treatment with glibenclamide in diabetic rats restored the activities of CAT, SOD, GST, G6PDH with activity of GPx being significantly increased (P < 0.05 ) from control rats. Aqueous floral extract administrations in diabetic rats restored the G6PDH and GPx activities, however activities of CAT, SOD and GST were significantly $(\mathrm{P}<0.05)$ lower from their respective control. Treatment of diabetic rats with ethanolic floral extract of $C$. officinalis restored the activities of SOD, CAT, GST and significantly $(\mathrm{P}<0.05)$ elevated activities of GPx and G6PDH than the normal control group (Figure 2).

Effect on Malondialdehyde (MDA) level Malondialdehyde, end product of lipid peroxidation is used as an indicator of cellular damage on administration 
Table 3 Effect of aqueous and ethanolic floral extracts of $C$. officinalis treatments on total plasma proteins (TPP), albumins, blood urea nitrogen (BUN), and creatinine (CR) of diabetic rats

\begin{tabular}{|c|c|c|c|c|}
\hline Groups & BUN & CR & TPP & Albumins \\
\hline Normal control & $51.92^{\mathrm{a}} \pm 3.00$ & $0.55^{\mathrm{a}} \pm 0.03$ & $7.81^{\mathrm{c}} \pm 0.31$ & $3.59^{b} \pm 0.13$ \\
\hline Aqueous extract & $55.05^{\mathrm{a}} \pm 3.73$ & $1.02^{\mathrm{b}} \pm 0.08$ & $6.92^{\mathrm{c}} \pm 0.30$ & $4.11^{\mathrm{c}} \pm 0.20$ \\
\hline Ethanolic extract & $54.93^{\mathrm{a}} \pm 4.37$ & $0.88^{\mathrm{b}} \pm 0.05$ & $7.19^{\mathrm{bc}} \pm 0.29$ & $3.96^{\mathrm{bc}} \pm 0.20$ \\
\hline Diabetic control & $97.27^{\mathrm{c}} \pm 5.56$ & $1.20^{\mathrm{c}} \pm 0.10$ & $5.94^{\mathrm{a}} \pm 0.30$ & $2.70^{\mathrm{a}} \pm 0.11$ \\
\hline Diabetic + Glibenclamide & $74.17^{\mathrm{c}} \pm 4.78$ & $0.60^{\mathrm{a}} \pm 0.04$ & $6.33^{\mathrm{b}} \pm 0.26$ & $2.80^{\mathrm{a}} \pm 0.11$ \\
\hline Diabetic + Aqueous extract & $83.31^{\mathrm{bc}} \pm 2.86$ & $0.59^{\mathrm{a}} \pm 0.03$ & $6.08^{\mathrm{a}} \pm 0.38$ & $2.38^{\mathrm{a}} \pm 0.18$ \\
\hline Diabetic + Ethanolic extract & $94.42^{c} \pm 6.97$ & $0.62^{\mathrm{a}} \pm 0.03$ & $5.97^{\mathrm{a}} \pm 0.26$ & $2.57^{\mathrm{a}} \pm 0.16$ \\
\hline \multicolumn{5}{|c|}{$\begin{array}{l}\text { Values are given as mean } \pm \text { SE of } 6 \text { animals unless otherwise stated } \\
\text { Values having different superscripts }(a, b, c \& d) \text { in a column are statistically different from one another at } 5 \% \text { level of } \\
\text { significance } \\
\text { Values of BUN, CR are expressed in } \mathrm{mg} / \mathrm{dl}\end{array}$} \\
\hline
\end{tabular}

Table 4: Effect of aqueous and ethanolic floral extracts of $C$. officinalis treatments on plasma activitie of transferases (AST \& ALT), phosphatase (ALP) and dehydrogenase (LDH) in diabetic rats

\begin{tabular}{|c|c|c|c|c|}
\hline Groups & ALT & AST & ALP & LDH \\
\hline Normal control & $\begin{array}{c}54.53^{\mathrm{a}} \pm \\
3.20\end{array}$ & $\begin{array}{c}68.04^{\mathrm{a}} \pm \\
5.82\end{array}$ & $\begin{array}{c}336.97^{\mathrm{a}} \pm \\
27.19\end{array}$ & $\begin{array}{c}277.07^{\mathrm{b}} \pm \\
18.89\end{array}$ \\
\hline Aqueous extract & $\begin{array}{c}89.87^{\mathrm{b}} \pm \\
7.82\end{array}$ & $\begin{array}{c}172.37^{\mathrm{c}} \pm \\
8.61\end{array}$ & $\begin{array}{c}434.58^{\mathrm{a}} \pm \\
35.94\end{array}$ & $\begin{array}{c}204.35^{\mathrm{a}} \pm \\
14.36\end{array}$ \\
\hline Ethanolic extract & $\begin{array}{c}94.03^{\mathrm{b}} \pm \\
2.30\end{array}$ & $\begin{array}{c}99.83^{\mathrm{b}} \pm \\
7.10\end{array}$ & $\begin{array}{c}460.53^{\mathrm{ab}} \pm \\
45.44\end{array}$ & $\begin{array}{c}233.42^{\mathrm{a}} \pm \\
21.86\end{array}$ \\
\hline Diabetic control & $\begin{array}{c}109.70^{c} \pm \\
7.95\end{array}$ & $\begin{array}{c}192.58^{\mathrm{c}} \pm \\
9.28\end{array}$ & $\begin{array}{c}640.55^{\mathrm{c}} \pm \\
53.80\end{array}$ & $\begin{array}{c}388.18^{\mathrm{bc}} \pm \\
29.11\end{array}$ \\
\hline Diabetic + Glibenclamide & $\begin{array}{c}59.21^{\mathrm{a}} \pm \\
2.51\end{array}$ & $\begin{array}{c}101.88^{\mathrm{b}} \pm \\
5.51\end{array}$ & $\begin{array}{c}343.92^{\mathrm{a}} \pm \\
26.37\end{array}$ & $\begin{array}{c}345.63^{\mathrm{c}} \pm \\
13.48\end{array}$ \\
\hline Diabetic + Aqueous extract & $\begin{array}{c}74.44^{\mathrm{b}} \pm \\
7.26\end{array}$ & $\begin{array}{c}106.60^{\mathrm{b}} \pm \\
5.94\end{array}$ & $\begin{array}{c}453.00^{\mathrm{a}} \pm \\
64.30\end{array}$ & $\begin{array}{c}266.97^{\mathrm{a}} \pm \\
27.96\end{array}$ \\
\hline Diabetic + Ethanolic extract & $\begin{array}{c}75.43^{b} \pm \\
6.57\end{array}$ & $\begin{array}{c}66.91^{\mathrm{a}} \pm \\
3.02\end{array}$ & $\begin{array}{c}574.35^{\mathrm{bc}} \pm \\
42.63\end{array}$ & $\begin{array}{c}222.38^{\mathrm{a}} \pm \\
19.17\end{array}$ \\
\hline
\end{tabular}

Values are given as mean \pm SE of 6 animals unless otherwise stated

Values having different superscripts $(a, b, c \& d)$ in a column are statistically different from one another at $5 \%$ level

of significance

Values of AST \& ALT (aspartate \& alanine aminotransferase), ALP (alkaline phosphatase) and LDH (lactate

dehydrogenase) are expressed in $\mathrm{U} / \mathrm{L}$ 
A)

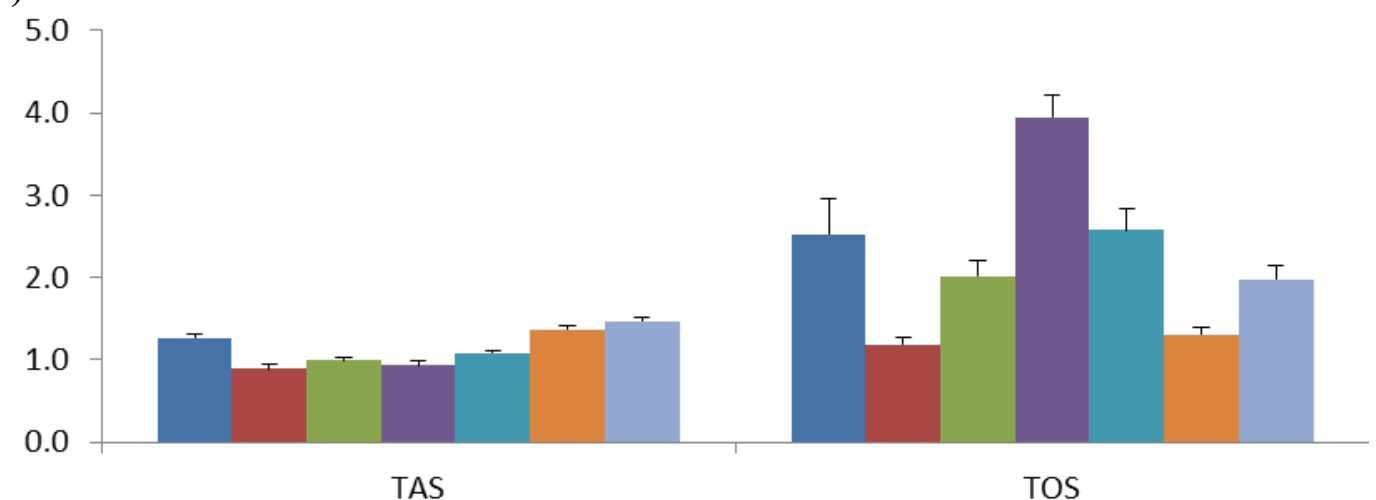

B) $\quad$ C)

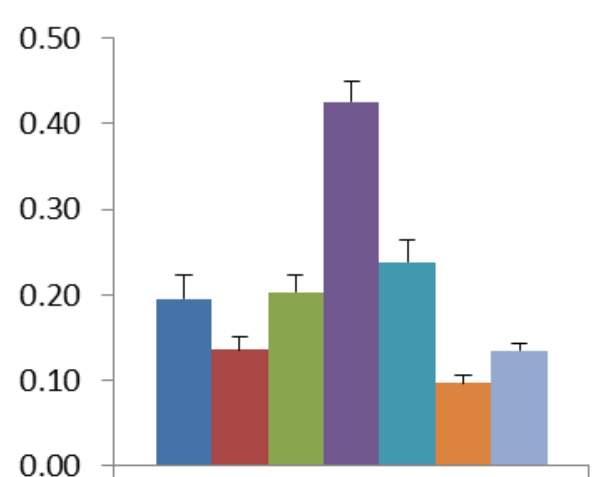

OSI

D)

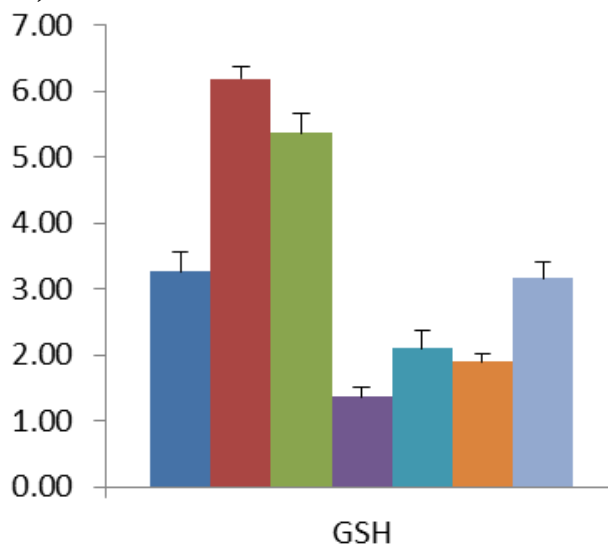

C)

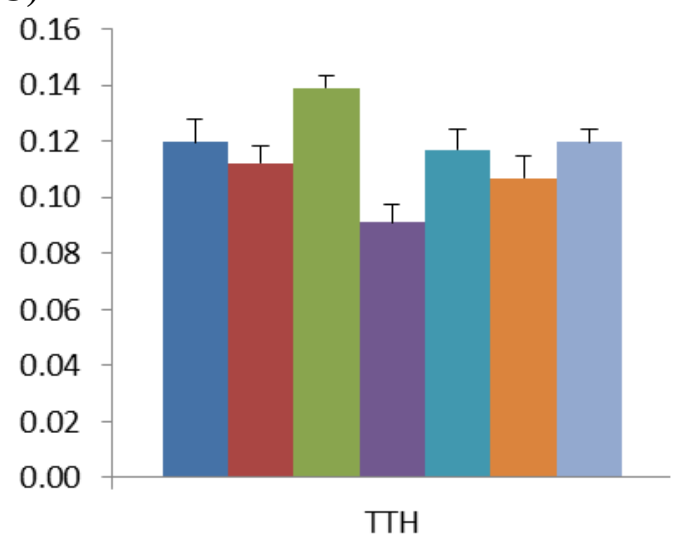

E)

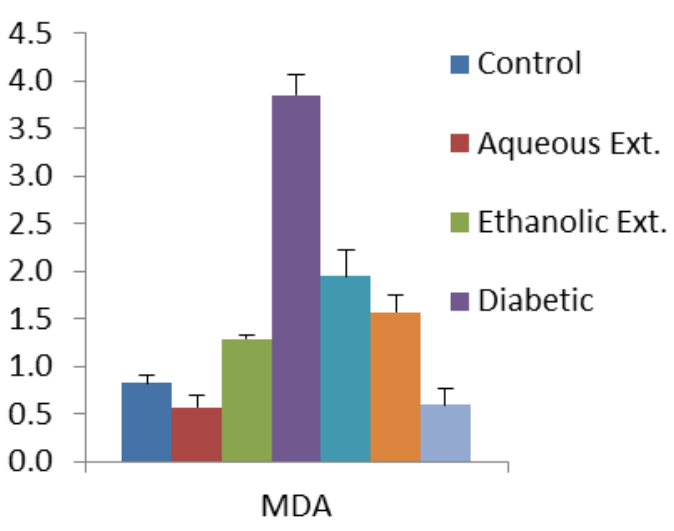

Figure 1 Effect of aqueous and ethanolic floral extracts of $C$. officinalis administrations on blood level of (A) TAS (mM), TOS (( $\mu \mathrm{mol} \mathrm{H}_{2} \mathrm{O}_{2}$ Equiv/ L), (B) OSI, (C) TTH (mM), (D) GSH (mM) and (E) MDA levels (nmole of MDA formed/ml/h) in diabetic rats. 
A)

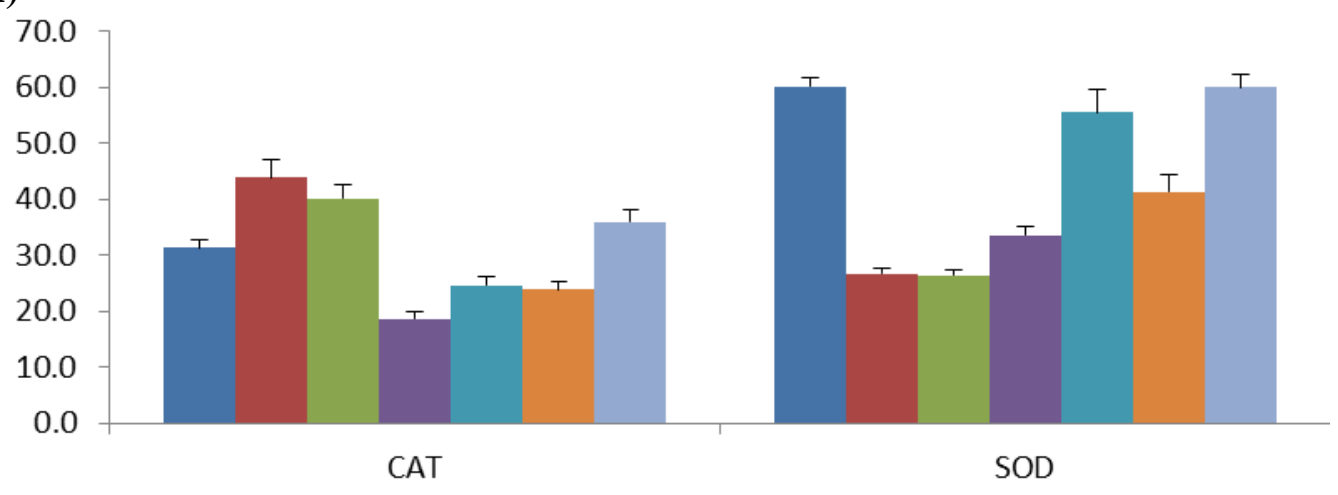

B)

C)

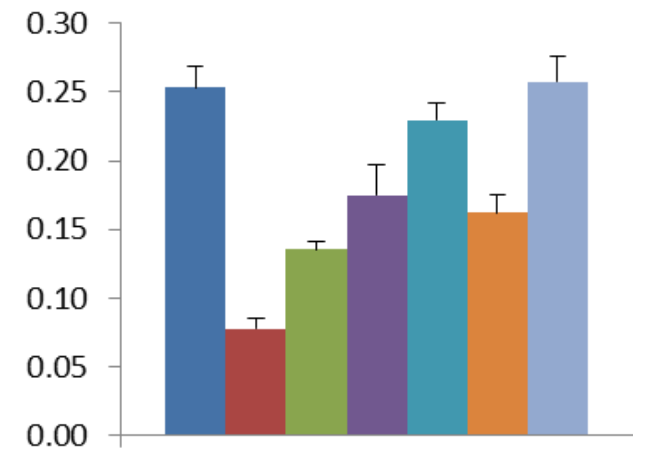

GST

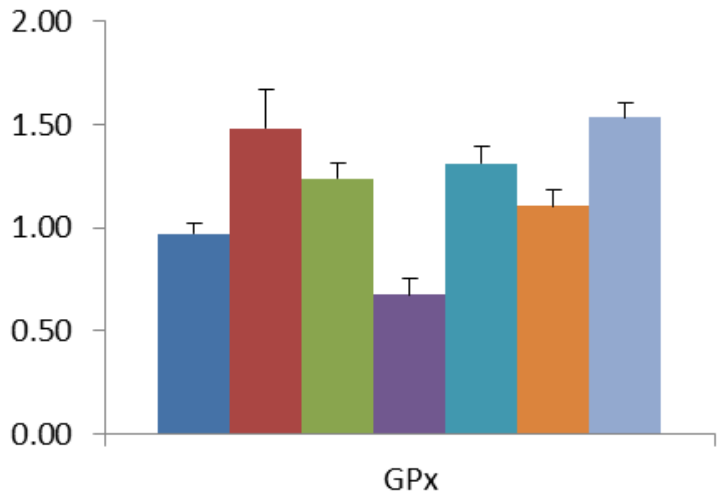

D)

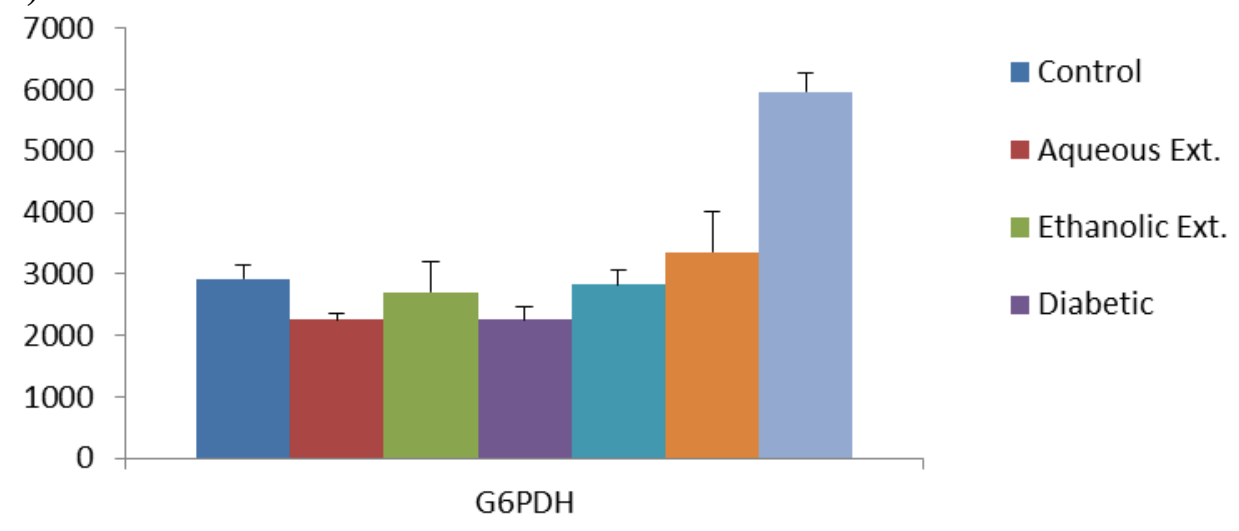

Figure 2 Effect of aqueous and ethanolic floral extracts of $C$. officinalis administrations on erythrocyte activities of (A) CAT ( $\mu \mathrm{mol} \mathrm{H}_{2} \mathrm{O}_{2}$ decomposed/ $\mathrm{min} / \mathrm{mg}$ of $\mathrm{Hb}$ ), SOD (Unit/ $\mathrm{mg}$ of $\mathrm{Hb}$ ), (B) GST ( $\mu \mathrm{mol}$ of CDNB conjugate formed/ $\mathrm{min} / \mathrm{mg}$ of $\mathrm{Hb}$ ) and (C) GPx (Unit/ $\mathrm{mg}$ of $\mathrm{Hb}$ ) and (D) G6PDH activities expressed in $\mathrm{U} / \mathrm{L}$ in diabetic rats 
of the toxicant and/disease condition. MDA level in diabetic rats was significantly $(\mathrm{P}<0.05)$ higher from the non-diabetic rats. Treatment of diabetic rats with glibenclamide significantly $(\mathrm{P}<0.05)$ reduced the level of MDA as compared to diabetic rats and values are still significantly $(\mathrm{P}<0.05)$ higher from the control animals. Diabetic rats exhibited significant $(\mathrm{P}<0.05)$ reduction in MDA level on treatment with aqueous floral extract of $C$. officinalis but with ethanolic floral extract significantly $(\mathrm{P}<0.05)$ reduced the MDA level as compared to diabetic rats and level was not significantly different from the normal control (Figure 2).

\section{Discussion}

Diabetes mellitus is a metabolic disorder characterized by hyperglycemia with impaired carbohydrate, fat and protein metabolism (33). In the last few decades, increasing attention has been paid to the development of herbal medicines as a newly emerging treatment for diabetic complications. Single intra peritoneal administration of STZ significantly increased the level of MBG primarily due to oxidative damage in $\beta$-cells of pancreas $(34,35)$. Persistent increased MBG causes glycation of proteins leading to increased level of $\mathrm{HbAlc}$. International expert committee guidelines have also recommended monitoring the level of $\mathrm{HbAlc}$ fraction to assess the intensity of diabetic complications (36). Evidence showed that glycation itself may induce the formation of oxygen-derived free radicals and is considered a very sensitive index for glycemic control and degree of oxidative stress in diabetes (3). Glycation of major cellular proteins of visceral organs are the major factor in the pathogenesis of diabetes associated complications $(3,37)$. Apart from this, AGEs proteins also get accumulated as persisting molecules in tissues and generate abnormalities in cellular functions (38). Repeated oral administrations of either aqueous or ethanolic floral extract of $C$. officinalis in diabetic rats restored the level of MBG and per cent $\mathrm{HbAlc}$ indicating the floral parts of plant has hypoglycemic potential in STZ induced diabetes. The exact mechanisms of lowering MBG and per cent HbAlc by plant extracts is not clear. Studies have reported that alkaloids and flavonoids present in the various plant extracts produce hypoglycemic action by restoring insulin levels either from pancreatic tissue or extra- pancreatic mechanisms and/or decrease in the intestinal absorption of glucose or stimulation of peripheral glucose utilization (39, 40). Rao et al. (41) reported terpenoids present in the plant extract reduce diabetic complications by inhibiting aldose reductase and formation of AGEs complex.

Elevated $\mathrm{HbAlc}$ in diabetic and non-diabetic subject has been regarded as an independent risk factor for cardiovascular disorders $(42,43)$. Alterations in lipid profile is the major risk for the atherosclerotic heart disease and in present study increased levels of TC, TG, LDL and reduced HDL level indicate the cardiovascular disorders associated with diabetes. Repeated administrations of aqueous or ethanolic floral extracts of $C$. officinalis reduced the levels of TC, TG and maintained the levels of $\mathrm{HDL}$ and LDL in diabetic rats showing that floral extracts have potential to correct the lipid profile in diabetic rats also. The similar observations have been reported from leaf fractions of C. officinalis (44). High concentrations of lycopene, coumarins and carotenoids present in floral extract of $C$. officinalis $(11,45)$ may contribute to hypolipidemic potential (44).

\section{Effect on renal parameters}

In diabetes, nephropathy, retinopathy, neuropathy etc are the major complications developed mainly due to persistent rise in blood glucose level. Intensity of diabetic complications in different organs depends on the duration of diabetes and glycemic control. Significantly increased activities of phosphatases, transferases and dehydrogenases and increased BUN and CR levels in the present study indicated altered renal functions. Studies have shown the increased glycation (AGEs) of functional and structural proteins is involved in the pathogenesis of renal and other cellular dysfunctions during diabetes $(46,47)$. Repeated oral administrations of either aqueous or ethanolic floral extract in diabetic rats restored the activities of ALP, LDH, ALT and CR level, whereas BUN level remains high. The restoration of blood glucose and correction muscular tissue functions may be responsible for the correction of $\mathrm{CR}$ levels on repeated oral administrations of floral extracts in diabetic rats. But, reduced level of plasma proteins in diabetic rats on treatment with extracts indicates increased protein catabolism which may be responsible for increased BUN level. The floral 
extract of $C$. officinalis is a rich source of polyphenolic compounds especially alkaloids, flavonoids and carotenoids (11). The flavonoids present in the floral extract reduce renal and muscular damage may be due to detoxifying ROS/RNS products by increasing the availability of GSH (48) and/or inhibitory effects on nitric oxide production in diabetic animals (49).

\section{Antioxidant indices}

Number of studies indicated that increased glycation of functional and structural proteins (AGEs formation) associated oxidative damage is primarily responsible for the diabetic complications (50). Although, mammalian cells are endowed with strong antioxidant defense comprising of enzymatic components like CAT, SOD, GPx, GST, G6PDH and non-enzymatic components (GSH, TTH) to scavenge these radicals for restoration of the antioxidant balance. In the present study increased plasma levels of TOS, OSI and reduced TAS, TTH, GSH levels indicate imbalance in antioxidant and oxidant ratio leading to oxidative stress in diabetic rats. Increased production of oxidants with reduced cellular antioxidant status in diabetic rats increased free radicals induced cellular damage as indicated by increased plasma levels of muscular and renal indices (51). Repeated administrations of aqueous floral extract of $C$. officinalis in diabetic rats significantly increased the TAS and restored the TOS and OSI to values of control group. However, treatment with ethanolic extract significantly increased TAS but failed to restore the levels of TOS and OSI in diabetic rats. Increased TAS values on repeated extract administration enhanced antioxidant defense either by direct scavenging the ROS/RNS radicals or increased levels of total thiols (TTH) and GSH levels (17).

The reduction in activities of CAT, SOD, GST, GPx and G6PDH in diabetic rats in present study indicates reduced scavenging mechanism leading to accumulation of these radicals in intra and extra cellular medium. The consequence of reduced activity of G6PDH leads to reduced cytosolic concentration of NADPH which is normally required as critical cofactor for CAT and glutathione reductase $(52,53)$ and makes cell vulnerable to oxidant damage (54). Repeated administration of ethanolic extract in diabetic rats restored the level of G6PDH which may be responsible for normalizing the activity of CAT and level of GSH by providing cytosolic concentration of NADPH. In mammalian tissues, thiols (protein and non-protein thiols) plays a pivotal role in scavenging small oxidants by directly interacting with them and provide protection against oxidative stress (cofactor for CAT, GPx) induced by reactive oxygen/nitrogen species (ROS/RNS). In the present study levels of total thiols (non-protein and protein -SH) reduced significantly in diabetic rats as compared to control group. Reduced GSH levels adversely affect the activities of SOD and GPx in diabetic rats (55).

Repeated administration of either aqueous or ethanolic extract of $C$. officinalis in diabetic rats normalized the activities of G6PDH, GST, GPx and CAT which catalyses/metabolizes the free radicals/ROS generated during hyperglycemia. Normalization of various parameters in diabetic rats by repeated administration of either aqueous or ethanolic floral extracts of $C$. officinalis may be due to presence of high polyphenolic and flavonoids constituents. Further in vitro studies have shown that floral extract have high total antioxidant capacity, free radicals, superoxide radicals, hydroxyl, and nitric oxide radicals scavenging potential $(11,57)$. Further presence of flavonoids, triterpenoids and alkaloids were identified in $C$. officinalis plants which may contribute to antidiabetic potential $(58,59)$. The flavonoids and triterpenoids posses direct antioxidant effect and also by induction of nuclear factor 2- antioxidant response element (Nrf2-ARE) involved in stimulating cellular defense $(60,61)$.

\section{Conclusion}

Hypoglycemic, hypolipidemic, restored antioxidant level, and reduced altered renal functions by the repeated administrations of floral extract of $C$. officinalis in diabetic rats. Further, modulatory effect was better in aqueous as compared to ethanolic floral extract of $C$. officinalis administration. Oxidative stress plays a central role in diabetes and its complications, thus supplementation with phytochemical ingredients endowed with high antioxidant potential could be of interest, by allowing a delay in the appearance or in the development of diabetic complications in animals.

\section{Acknowledgements}

Authors thank to the Dean, Faculty of Veterinary Sciences and Animal Husbandry, R S Pura, Jammu for 
providing necessary facilities for conducting the research.

\section{Conflict of Interest}

Authors declare there are no conflicts of interest.

\section{References}

1. Whiting DR, Guariguata L, Weil C, Shaw J. IDF diabetes atlas: global estimates of the prevalence of diabetes for 2011 and 2030. Diabetes Res Clin Pract 2011;94:311-21.

2. Zhang P, Zhang X, Brown J, Vistisen D, Sicree R, Shaw J, et al. Global healthcare expenditure on diabetes for 2010 and 2030. Diabetes Res Clin Pract 2010;87:293-301.

3. Bravi MC, Armiento A, Laurenti O, Cassone-Faldetta M De Luca O, Moretti A, et al. Insulin decreases intracellular oxidative stress in patients with type 2 diabetes mellitus. Metabolism 2006;55:691-5.

4. Booth AA, Khalifah RG, Todd P, Hudson BG. In vitro kinetic studies of formation of antigenic advanced glycation end products (AGEs). Novel inhibition of postAmadori glycation pathways. J Biol Chem 1997;272:5430-7.

5. Vlassara H, Palace MR. Diabetes and advanced glycation endproducts. J Intern Med 2002;251:87-101

6. Okamoto T. Safety of quercetin for clinical application (Review). Int J Mol Med 2005;16:275-8.

7. Grover JK, Yadav S, Vats V. Medicinal plants of India with anti-diabetic potential. J Ethnopharmacol 2002;81:81-100.

8. Ylonen K, Alfthan G, Groop L, Saloranta C, Aro A Virtanen SM. Dietary intakes and plasma concentrations of carotenoids and tocopherols in relation to glucose metabolism in subjects at high risk of type 2 diabetes: The Botnia Dietary Study. Am J Clin Nutr 2003;77:1434-41.

9. Lagarto A, Bueno V, Guerra I, Valdés O, Vega Y, Torres L. Acute and subchronic oral toxicities of Calendula officinalis extract in Wistar rats. Exp Toxicol Pathol 2011;63:387-91.

10. Raal A, Kirsipuu K. Total flavonoid content in varieties of Calendula officinalis L. originating from different countries and cultivated in Estonia. Nat Prod Res 2011;25:658-62.

11. Verma PK, Raina R, Sultana M. Phytochemical constituents and antioxidant potential in floral extracts of Calendula officinalis Linn. World J Pharmaceut Res 2014;3:2067-83

12. Neukiron H, D'Ambrosio M, Dalla via J, Guerriero A Simultaneous quantitative determination of eight triterpenoid monoesters from flowers of 10 Varieties of Calendula officinalis $\mathrm{L}$ and characterization of a new triterpenoid monoester. Phytochem Anal 2004;15:30-5.

13. Naguib NY, Khalil MY, Sherbeny SE. A comparative study on the productivity and chemical constituents of various sources and species of Calendula plants as affected by two foliar fertilizers. J Applied Sci Res 2005;1:176-89.
14. Silva EJ, Gonçalves ES, Aguiar F, Evêncio LB, Lyra MM, Coelho MC, et al. Toxicological studies on hydroalcohol extract of Calendula officinalis L. Phytother Res 2007;21:332-6.

15. Preethi KC, Kuttan R. Wound healing activity of flower extract of Calendula officinalis. J Basic Clin Physiol Pharmacol 2009;20:73-9.

16. Rusu MA, Tamas M, Puica C, Roman I, Sabadas M. The hepatoprotective action of ten herbal extracts in $\mathrm{CCl}_{4}$ intoxicated liver. Phytother Res 2005;19:744-9.

17. Preethi KC, Kuttan R. Hepato and reno protective action of Calendula officinalis L. flower extract. Indian J Exp Biol 2009;47:163-8.

18. Verma PK, Raina R, Sultana M, Singh M, Kumar P. Total antioxidant and oxidant status of plasma and renal tissue of cisplatin-induced nephrotoxic rats: Protection by floral extracts of Calendula officinalis Linn. Ren Fail 2016;38:142-50.

19. Hamburger M, Adler S, Baumann D, Förg A, Weinreich B. Preparative purification of the major anti-inflammatory triterpenoid esters from Marigold (Calendula officinalis). Fitoterapia 2003;74:328-38.

20. Pandit R, Phadke A, Jagtap A. Antidiabetic effect of Ficus religiosa extract in streptozotocin-induced diabetic rats. J Ethnopharmacol 2010;128:462-6.

21. Nathan DM, Singer DE, Hurxthal K, Goodson JD. The clinical information value of the glycosylated hemoglobin assay. N Engl J Med 1984;310:341-6.

22. Re R, Pellegrini N, Proteggente A, Pannala A, Yang M, Rice-evans C. Antioxidant activity applying an improved ABTS radical cation decolorization assay. Free Radic Biol Med 1999;26:1231-7.

23. Erel O. A new automated colorimetric method for measuring total oxidant status. Clin Biochem 2005;38:1103-11.

24. Aycicek A, Erel O, Kocyigit A, Selek S, Demirkol MR. Breast milk provides better antioxidant power than does formula. Nutrition 2006;22:616-9.

25. Deutsch J. Maleimide as an inhibitor in measurement of erythrocyte glucose-6-phosphate dehydrogenase activity. Clin Chem 1978;24:885-9.

26. Aebi, HE. Catalase, In: Bergmeyer HU, eds. Methods of Enzymatic Analysis, New York, Academic Press; 1983:276-286.

27. Hafeman DG, Sunde RA, Hoekstra WG. Effect of dietary selenium on erythrocyte and liver glutathione peroxidase in the rat. J Nutr 1974;104:580-7.

28. Marklund S, Marklund G. Involvement of superoxide anion radical in autoxidation of pyrogallol and a convenient assay for superoxide dismutase. Eur J Biochem 1974;47:469-74.

29. Habig WH, Pabst MJ, Jakoby WB. Gultathione-Stransferases: The first enzymatic step in mercapturic acid formation. J Biol Chem 1974;249:7130-9.

30. Motchnik AP, Frei B, Ames NB. Measurement of antioxidants in human blood plasma, Protein thiols. In: Packer, L., (Eds.) Oxygen radicals in biological systems, 
Methods in Enzymology. California, Academic Press, 1994:234(D) pp: 273-274.

31. Shafiq-ur-rehman. Lead-induced regional lipid peroxidation in brain. Toxicol Lett 1984;21:333-7.

32. Beutler E. Red cell metabolism, a manual of biochemical methods $2^{\text {nd }}$ Edn, Grune Stratton, New York. 1975 pp. 6769 ,

33. Yanardağ R, Bolkent S, Ozsoy-saçan O, Karabulut-bulan O. The effects of chard (Beta vulgaris L. var. cicla) extract on the kidney tissue, serum urea and creatinine levels of diabetic rats. Phytother Res 2002;16:758-61.

34. Szkudelski T. The mechanism of alloxan and streptozotocin action in B cells of the rat pancreas. Physiol Res 2001;50:537-46.

35. Del prato S, Bianchi C, Marchetti P. beta-cell function and anti-diabetic pharmacotherapy. Diabetes Metab Res Rev 2007;23:518-27.

36. WHO. Use of glycosylated haemoglobin $(\mathrm{HbAlc})$ in the diagnosis of diabetes mellitus. World Health Organization, Geneva. 2011. WHO/NMH/CHP/CPM/11.1.

37. Nishikawa T, Edelstein D, Brownlee M. The missing link: a single unifying mechanism for diabetic complications. Kidney Int Suppl 2000;77:S26-30.

38. Brownlee M. Biochemistry and molecular cell biology of diabetic complications. Nature 2001;414:813-20.

39. Anurakkun NJ, Bhandari MR, Kawabata J. Alpha glucosidase inhibitors from Devil tree (Alstonia scholaris). Food Chem 2007;103:1319-23.

40. Jung M, Park M, Lee HC, Kang YH, Kang ES, Kim SK. Antidiabetic agents from medicinal plants. Curr Med Chem 2006;13:1203-18

41. Rao AR, Veeresham C, Asres K. In vitro and in vivo inhibitory activities of four Indian medicinal plant extracts and their major components on rat aldose reductase and generation of advanced glycation endproducts. Phytother Res 2013;27:753-60.

42. Selvin E, Coresh J, Golden SH, Brancati FL, Folsom AR, Steffes MW. Glycemic control and coronary heart disease risk in persons with and without diabetes: the atherosclerosis risk in communities study. Arch Intern Med 2005;165:1910-6.

43. Khaw KT, Wareham N, Bingham S, Luben R, Welch A, Day N. Association of hemoglobin Alc with cardiovascular disease and mortality in adults: the European prospective investigation into cancer in Norfolk. Ann Intern Med 2004;141:413-20.

44. Chakraborthy GS, Arora R, Majee C. Anti diabetic and antihyperlipidemic effect of hydro-alcoholic extract of Calendula officinalis. Int Res J Pharm 2011;2:61-5.

45. Kishimoto S, Maoka T, Sumitomo K, Ohmiya A. Analysis of carotenoid composition in petals of calendula (Calendula officinalis L.). Biosci Biotechnol Biochem 2005;69:2122-8

46. Krishnamurti U, Rondeau E, Sraer JD, Michael AF, Tsilibary EC. Alterations in human glomerular epithelial cells interacting with nonenzymatically glycosylated matrix. J Biol Chem 1997;272:27966-70.
47. Kutner NG, Johansen KL, Zhang R, Huang Y, Amaral S. Perspectives on the new kidney disease education benefit: early awareness, race and kidney transplant access in a USRDS study. Am J Transplant 2012;12:1017-23.

48. Sefi M, Fetoui H, Soudani N, Chtourou Y, Makni M, Zeghal N. Artemisia campestris leaf extract alleviates early diabetic nephropathy in rats by inhibiting protein oxidation and nitric oxide end products. Pathol Res Pract 2012;208:157-62.

49. Fang XK, Gao J, Zhu DN. Kaempferol and quercetin isolated from Euonymus alatus improve glucose uptake of 3T3-L1 cells without adipogenesis activity. Life Sci 2008;82:615-22.

50. Giardino I, Edelstein D, Brownlee M. BCL-2 expression or antioxidants prevent hyperglycemia-induced formation of intracellular advanced glycation endproducts in bovine endothelial cells. J Clin Invest 1996;97:1422-8.

51. Karadag-oncel E, Erel O, Ozsurekci Y, Caglayik DY, Kaya A, Mustafa GG, et al. Plasma oxidative stress and total thiol levels in Crimean-Congo hemorrhagic fever. Jpn J Infect Dis 2014;67:22-6.

52. Gaskin RS, Estwick D, Peddi R. G6PD deficiency: its role in the high prevalence of hypertension and diabetes mellitus. Ethn Dis 2001;11:749-54.

53. Felix K, Rockwood LD, Pretsch W, Bornkamm GW, Janz S. Redox imbalance and mutagenesis in spleens of mice harboring a hypomorphic allele of $\operatorname{Gpdx}(\mathrm{a})$ encoding glucose 6-phosphate dehydrogenase. Free Radic Biol Med 2003;34:226-32.

54. Zhang Z, Apse K, Pang J, Stanton RC. High glucose inhibits glucose-6-phosphate dehydrogenase via cAMP in aortic endothelial cells. J Biol Chem 2000;275:40042-7.

55. Myhrstad MC, Carlsen H, Nordström O, Blomhoff R, Moskaug JØ. Flavonoids increase the intracellular glutathione level by transactivation of the gammaglutamylcysteine synthetase catalytical subunit promoter. Free Radic Biol Med 2002;32:386-93.

56. Fonseca YM, Catini CD, Vicentini FT, Cardoso JC, Cavalcanti de albuquerque junior RL, Vieira fonseca MJ. Efficacy of marigold extract-loaded formulations against UV-induced oxidative stress. J Pharm Sci 2011;100:218293.

57. Upadhya S, Shanbhag KK, Suneetha G, Balachandra naidu M, Upadhya S. A study of hypoglycemic and antioxidant activity of Aegle marmelos in alloxan induced diabetic rats. Indian J Physiol Pharmacol 2004;48:476-80.

58. Matysik G, Wójciak-kosior M, Paduch R. The influence of Calendulae officinalis flos extracts on cell cultures, and the chromatographic analysis of extracts. J Pharm Biomed Anal 2005;38:285-92.

59. Liang L, Gao C, Luo M, Wang W, Zhao C, Zu Y, et al. Dihydroquercetin (DHQ) induced HO-1 and NQO1 expression against oxidative stress through the Nrf2dependent antioxidant pathway. J Agric Food Chem 2013;61:2755-61. 
60. Gan L, Johnson JA. Oxidative damage and the Nrf2-ARE pathway in neurodegenerative diseases. Biochim Biophys Acta 2014;1842:1208-18. 